\title{
In vitro clonal propagation of Acacia mangium Willd. and its evaluation of genetic stability through RAPD marker
}

\author{
Rashmi M. NANDA, Premananda DAS, Gyana Ranjan RouT* \\ Plant Biotechnology Division, Plant Tissue Culture Laboratory, Regional Plant Resource Centre, Bhubaneswar- 751 015, Orissa, India
}

(Received 28 October 2002; accepted 5 June 2003)

\begin{abstract}
An in vitro propagation of a tropical leguminous tree, Acacia mangium, has been established. Induction of bud sprout was obtained from mature nodal explants of 10-years-old tree of Acacia mangium on Murashige and Skoog (MS) [10] basal medium supplemented with 6-benzylaminopurine (BAP) $(1.0 \mathrm{mg} / \mathrm{L})$, gibberellic acid $\left(\mathrm{GA}_{3}\right) 1.0 \mathrm{mg} / \mathrm{L}$ and indole-3-acetic acid (IAA) $0.05 \mathrm{mg} / \mathrm{L}$. The rate of multiplication was obtained on MS medium supplemented with $1.5 \mathrm{mg} / \mathrm{L}$ BAP, $0.05 \mathrm{mg} / \mathrm{L}$ IAA and $100 \mathrm{mg} / \mathrm{L}$ adenine sulfate (Ads). The multiplication rate varied from 1 to 8 depending on the growth regulators used. Excised shoots were rooted on half-strength MS basal salts supplemented with $0.5 \mathrm{mg} / \mathrm{L}$ indole-3-butyric acid (IBA) or indole-3-acetic acid (IAA) and $20 \mathrm{~g} / \mathrm{L}$ (w/v) sucrose after 13-14 days of culture. The micropropagated plantlets have been acclimatized and successfully transferred to soil. The micropropagated plantlets appeared morphologically similar to the mother plant. No variation was detected among the micropropagated plants by the use of Randomly Amplified Polymorphic DNA (RAPD) markers.
\end{abstract}

in vitro / legume tree / multiplication / micro-propagation / RAPD marker

Résumé - Propagation de clones in vitro d'Acacia mangium Willd., et évaluation de leur stabilité génétique avec un marquage RADP. On a réalisé la propagation in vitro d'un arbre, Acacia mangium, de la famille des légumineuses. L'induction de bourgeons débourrés a été obtenue à partir d'explants de bois aoûté prélevés sur des arbres âgés de 10 ans, cultivés dans le milieu de base de Murashige et Skoog (MS) auquel on a ajouté de la benzylaminopurine (BAP) $(1,0 \mathrm{mg} / \mathrm{L})$, de l'acide gibbérelique $\left(\mathrm{GA}_{3}\right)(1,0 \mathrm{mg} / \mathrm{L})$ et de l'acide indol-3 acétique (IAA) $(0,05 \mathrm{mg} / \mathrm{L})$. Pour la phase multiplication on a utilisé le milieu MS avec addition de 1,5 mg/L de BAP, 0,05 mg/L d'IAA et $150 \mathrm{mg} / \mathrm{L}$ de sulfate d'adénine (Ads). Le taux de multiplication a varié de 1 à 8 selon les régulateurs de croissance utilisés. L'enracinement des pousses a été obtenu avec le milieu MS dilué de moitié, additionné de $0,5 \mathrm{mg} / \mathrm{L}$ d'acide indol butyrique (IBA) ou d'acide indol-3 acétique (IAA) et de $20 \mathrm{~g} / \mathrm{L}$ de (w/v) saccharose après 13 à 14 jours de culture. Les plantules issues de cette micropropagation ont été acclimatées et transférées avec succès sur le terrain. Elles étaient apparemment similaires à la plante mère sur le plan morphologique. Aucune variabilité n'a pu être détectée entre plantules par l'utilisation de marqueurs DNA (RAPD).

multiplication de légumineuses ligneuses / micropropagation / marqueurs RAPD

\section{INTRODUCTION}

Micropropagation of tree species offers a rapid means of producing clonal planting stock for afforestation, woody biomass production and conservation of elite germplasm. In general, the woody plants are difficult to regenerate under in vitro conditions but recently some success have been achieved in a few leguminous tree species $[5,9,11,15,16]$. There were some successful reports of development of plantlets from callus raised through seedling shoot tip cultures and from cotyledonary buds and nodal explant $[11,15]$. Acacia mangium Willd. (family Leguminosae) is a tropical multipurpose legume tree native to Papua New Guinea and the Eastern provinces of Indonesia, with extension to Northern Australia [6]. It grows in the humid tropical countries of South East Asia, especially in acid and degraded soils, to which it can restore fertility owing to its natural nitrogen fixing ability. Besides, this tree is used as a source of pulpwood production [6]. Conventional methods of propagation of Acacia mangium, sexual as well as vegetative, are beset with many problems that restrict their multiplication on a large scale. Cloning of mature trees is generally preferred over seedling explants because it is often not possible to determine whether these embryos or seedlings have the genetic potential to develop the desired qualities later in their life cycle. In vitro culture techniques have great potential for clonal propagation of superior genotypes of this legume species for reforestation programmes as well as utilization in paper industries. So far, there is no report on shoot multiplication from mature

*Corresponding author: grrout@hotmail.com; grrout@ rediffmail.com 
explant of Acacia mangium. This communication describes a successful protocol on in vitro clonal propagation of Acacia mangium from nodal explants of a mature tree and determines the genetic stability of the micropropagated plants through RAPD marker.

\section{MATERIALS AND METHODS}

\subsection{Explant source}

Semi-mature growing twigs $(8-10 \mathrm{~cm}$ long) were collected from a 10 -year-old tree of $A$. mangium and washed with $5 \%(\mathrm{v} / \mathrm{v})$ detergent solution 'Teepol' (Qualigen, India) for $10 \mathrm{~min}$. Subsequently, the long twigs were cut into smaller segments about 3-4 cm long and surface sterilized with $0.1 \%(\mathrm{w} / \mathrm{v})$ aqueous mercuric chloride solution for 20 min and washed 4-5 times in sterile distilled water. Each segment was further cut into 1-2 cm having one node each.

\subsection{Culture condition}

The nodal explants were cultured on MS [10] medium supplemented with different concentrations of 6-benzylaminopurine (BAP: 0, 0.5, 1.0, 1.5 and $2.0 \mathrm{mg} / \mathrm{L})$, Kinetin $(\mathrm{Kn}: 0,0.5,1.0,1.5$ and $2.0 \mathrm{mg} / \mathrm{L})$, adenine sulfate (Ads: $0,50,100 \mathrm{mg} / \mathrm{L}$ ), indole-3-acetic acid (IAA: 0 , $0.05,0.10,0.25 \mathrm{mg} / \mathrm{L}$ ) or 1-naphthylacetic acid (NAA: 0, 0.05, 0.10, $0.25 \mathrm{mg} / \mathrm{L})$ and gibberellic acid $\left(\mathrm{GA}_{3}: 0,0.5,1.0,1.5 \mathrm{mg} / \mathrm{L}\right)$ alone or in combination. All media were adjusted to $\mathrm{pH} 5.7$ using $0.1 \mathrm{~N} \mathrm{HCl}$ or $0.1 \mathrm{~N} \mathrm{NaOH}$ before autoclaving. The medium was gelled with $0.8 \%$ (w/v) agar (Qualigen, India). Routinely, $20 \mathrm{~mL}$ of molten medium was dispensed into a culture tube $(25 \times 150 \mathrm{~mm})$ and plugged with nonabsorbant cotton wrapped in one layer of cheese cloth. The cultures were steam sterilized at $1.06 \mathrm{~kg} \cdot \mathrm{cm}^{-2}$ for $15 \mathrm{~min}$. All cultures were incubated in $16 \mathrm{~h}$ light $/ 8 \mathrm{~h}$ dark photoperiod under light intensity of $50 \mu \mathrm{E} \mathrm{m}^{-2} \mathrm{~s}^{-1}$ provided by cool white fluorescent light (Philips, India) at $25 \pm 2{ }^{\circ} \mathrm{C}$ with $55 \%$ relative humidity. Each treatment had 20 culture tubes and the experiment was repeated thrice. The effects of different treatments were quantified as the mean number of multiple shoots/culture. The data were statistically analysed by the Duncan Multiple range test [4].

\subsection{Induction of rooting}

In vitro raised shoots measuring about $2-3 \mathrm{~cm}$ growing on multiplication medium were excised and cultured on half-strength MS basal salts supplemented with $0,0.25,0.5,1.0$ and $1.5 \mathrm{mg} / \mathrm{L}$ of IAA, IBA and NAA alone or in combination for induction of rooting. In case of rooting experiment, 10 replicates per treatment were taken and the experiment was repeated thrice. The cultures were examined every weeks and the morphological changes were recorded on the basis of visual observations. The effects of different treatments were quantified as the mean percentage of rooting.

\subsection{DNA extraction}

DNA was extracted from fresh leaves derived from twenty in vitro raised plants and from the field grown mother plant by the cetyltrimethyl ammonium bromide, EMERK (CTAB) method [2]. Approximately, $250 \mathrm{mg}$ of fresh leaves were ground to powder in liquid nitrogen using a mortar and pestle. The ground powder was transferred to a $25 \mathrm{~mL}$ tube with $10 \mathrm{~mL}$ of CTAB buffer: $2 \%$ (w/v) CTAB, $1.4 \mathrm{M}$ $\mathrm{NaCl}, 20 \mathrm{mM}$ EDTA, $100 \mathrm{mM}$ Tris-HCl pH 8.0, and $0.2 \%(\mathrm{v} / \mathrm{v})$ $\beta$-mercaptoethanol. The homogenate was incubated at $60{ }^{\circ} \mathrm{C}$ for $2 \mathrm{~h}$, extracted with an equal volume of chloroform: iso-amyl alcohol (24:1), and centrifuged at $10000 \mathrm{rpm}$ for $20 \mathrm{~min}$. DNA was precipitated from the aqueous phase by mixing with an equal volume of isopropanol. After centrifugation at $10000 \mathrm{rpm}$ for $10 \mathrm{~min}$, the DNA pellet was washed with $70 \%$ ethanol, air dried, and resuspended in $10 \mathrm{mM}$ Tris pH 8.0, 0.1 mM EDTA buffers. DNA quantity was estimated spectrophotometrically by measuring the absorbance at $260 \mathrm{~nm}$.

\subsection{PCR amplification}

Twenty arbitrary 10-base primers (Operon Technologies Inc., Alameda, California) were used for Polymerase Chain Reaction (PCR). Amplification reactions were performed in $25 \mu \mathrm{L}: 2.0 \mu \mathrm{L}$ of $1.25 \mathrm{mM}$ each of dNTP's, $15 \mathrm{ng}$ of the primer, $1 \times$ Taq polymerase buffer, $0.5 \mathrm{U}$ of Taq DNA polymerase (Genei, India) and $20 \mathrm{ng}$ of genomic DNA. DNA amplification was performed in a PTC 100 DNA Thermal Cycler (M.J. Research, Inc., Watertown, MA, USA) programmed for 45 cycles: 1 st cycle of $3.5 \mathrm{~min}$ at $94^{\circ} \mathrm{C}, 1 \mathrm{~min}$ at $37^{\circ} \mathrm{C}$ and $2 \mathrm{~min}$ at $72{ }^{\circ} \mathrm{C}$; then 44 cycles each of $1 \mathrm{~min}$ at $94{ }^{\circ} \mathrm{C}, 1 \mathrm{~min}$ at $37{ }^{\circ} \mathrm{C}, 2 \mathrm{~min}$ at $72^{\circ} \mathrm{C}$ followed by one final extension cycle of $7 \mathrm{~min}$ at $72{ }^{\circ} \mathrm{C}$. Amplified products were electrophoresed in a $1.2 \%(\mathrm{w} / \mathrm{v})$ agarose (Sigma, USA) gels with $1 \times$ TAE buffer, stained with ethidium bromide, and photographed under ultraviolet (UV) light. The size of the amplification products were estimated for a 100-bp (100-bp to $3.0 \mathrm{~kb}$ ) ladder (M B I. Fermentas Inc.). All the reactions were repeated at least thrice.

\subsection{Amplified DNA marker scoring}

Amplified DNA markers were scored as present or absent both in the regenerated and the mother plants. Electrophoretic DNA bands of low visual intensity that could not be readily distinguished as present or absent were considered ambiguous markers and were not scored.

\subsection{Acclimatization}

Rooted plantlets were removed from the culture tube. After thorough washing of the roots in tap water, the plantlets were transferred to sterile sandy soil at the ratio of 1:1 (garden soil: sand) into earthen pots and kept under high humidity $(70 \%)$ in a greenhouse with temperature $\left(30 \pm 2{ }^{\circ} \mathrm{C}\right)$ for acclimatization.

\section{RESULTS AND DISCUSSION}

\subsection{Multiplication rate}

The present investigation was carried out to explore the morphogenic potential of Acacia mangium by using different combinations of growth regulators. The nodal explants resumed new bud growth by proliferating the axillary shoot within 23 weeks of culture. Out of the various cytokinins tested, BAP was the most effective for inducing bud break and growth in axillary meristems. Kinetin alone or in combination did not show any positive response on bud growth (data not shown). No bud sprout was obtained in media without growth regulator. The result also showed that the medium supplemented with $\mathrm{GA}_{3}$ alone or in combination with BAP favour positive response on bud sprout (Tab. I). The maximum bud break was observed in nodal explants cultured on MS medium supplemented with $1.0 \mathrm{mg} / \mathrm{L} \mathrm{BAP}, 1.0 \mathrm{mg} / \mathrm{L} \mathrm{GA}_{3}$ and $0.05 \mathrm{mg} / \mathrm{L} \mathrm{IAA}$ (Fig. 1a). Within 4 weeks of culture, the axillary meristems elongated up to $2-3 \mathrm{~cm}$ in height. Similar results were reported in other legume trees $[9,16]$. Regarding shoot multiplication, 

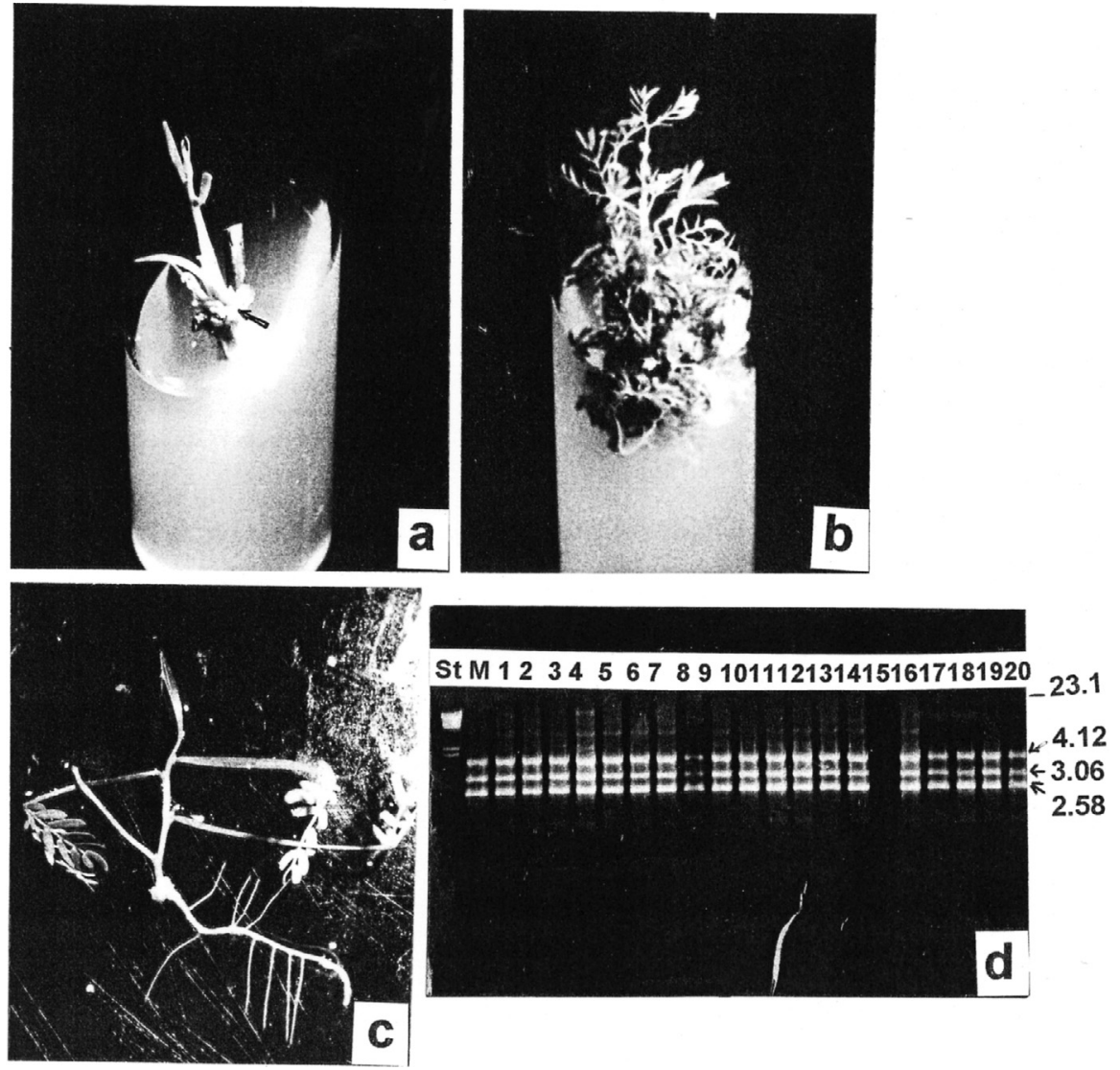

Figure 1. Micropropagation of Acacia mangium. (a) Development of bud sprout from nodal explants (arrow) of Acacia mangium on MS medium supplemented with $1.0 \mathrm{mg} / \mathrm{L}$ BAP, $1.0 \mathrm{mg} / \mathrm{L} \mathrm{GA} 3$ and $0.05 \mathrm{mg} / \mathrm{L} \mathrm{IAA}$ after 15 days of culture. (b) Induction of multiple shoots from nodal explants on MS medium supplemented with $1.5 \mathrm{mg} / \mathrm{L}$ BAP, $100 \mathrm{mg} / \mathrm{L}$ Ads and $0.05 \mathrm{mg} / \mathrm{L}$ IAA after 4 weeks of culture. (c) Rooted plantlet ready for ex vitro transfer. (d) RAPD profiles of micropropagated plants from nodal explants of Acacia mangium using primer OPC - 04 (5'-CCGCATCTAC-3'). Lane M shows RAPD bands from the field grown mother plant. Arrow indicates the size of the marker. Lanes 1-19 show RAPD products from micropropagated plants.

Table I. Bud sprout responses of nodal explants of Acacia mangium on MS medium supplemented with different concentrations of BA, GA 3 , IAA, NAA and $3 \%(\mathrm{w} / \mathrm{v})$ sucrose under $16 \mathrm{~h}$ photoperiod at $25 \pm 2{ }^{\circ} \mathrm{C}$ after one week of culture.

\begin{tabular}{|c|c|c|c|c|c|}
\hline \multicolumn{4}{|c|}{$\mathrm{MS}+$ growth regulator $(\mathrm{mg} / \mathrm{L})$} & \multirow{2}{*}{\multicolumn{2}{|c|}{$\begin{array}{l}\text { Percent of bud sprouting (\%) } \\
\qquad(\text { mean } \pm \text { S.E. })^{*}\end{array}$}} \\
\hline BAP & $\mathrm{GA}_{3}$ & IAA & NAA & & \\
\hline 0 & 0 & 0 & 0 & 0 & \\
\hline 0.5 & 0 & 0 & 0 & $28.8 \pm 1.2$ & $\mathrm{~b}$ \\
\hline 1.0 & 0 & 0 & 0 & $42.6 \pm 2.4$ & $\mathrm{~d}$ \\
\hline 0 & 0.5 & 0 & 0 & $26.2 \pm 1.4$ & $\mathrm{a}$ \\
\hline 0 & 1.0 & 0 & 0 & $36.8 \pm 1.2$ & $\mathrm{c}$ \\
\hline 0 & 1.5 & 0 & 0 & $46.2 \pm 2.2$ & $\mathrm{e}$ \\
\hline 1.0 & 0.5 & 0 & 0 & $58.6 \pm 1.0$ & $\mathrm{~h}$ \\
\hline 1.0 & 1.0 & 0 & 0 & $64.7 \pm 2.3$ & $\mathrm{j}$ \\
\hline 1.5 & 1.0 & 0 & 0 & $68.2 \pm 1.8$ & 1 \\
\hline 1.0 & 1.0 & 0.05 & 0 & $74.6 \pm 2.4$ & $\mathrm{n}$ \\
\hline 1.5 & 1.0 & 0.05 & 0 & $72.4 \pm 1.6$ & $\mathrm{~m}$ \\
\hline 1.0 & 1.0 & 0 & 0.05 & $56.8 \pm 1.2$ & $g+$ \\
\hline 1.5 & 1.0 & 0 & 0.05 & $58.4 \pm 1.0$ & $\mathrm{~h}+$ \\
\hline 1.0 & 1.5 & 0.05 & 0 & $66.2 \pm 2.3$ & $\mathrm{k}$ \\
\hline 1.0 & 1.5 & 0 & 0.05 & $54.3 \pm 1.6$ & $f+$ \\
\hline 1.0 & 1.0 & 0.10 & 0 & $62.7 \pm 1.8$ & $\mathrm{i}$ \\
\hline
\end{tabular}

\footnotetext{
* 20 replicates per treatment; repeated thrice. Means having same letters are not significantly different by Duncan's multiple range test at the level of
} $5 \% .+$ Callusing at the basal end. 
Table II. Effect of cytokinins on shoot multiplication from nodal explants of Acacia mangium after 4 weeks of culture.

\begin{tabular}{|c|c|c|c|c|c|}
\hline \multicolumn{4}{|c|}{$\mathrm{MS}+$ growth regulators $(\mathrm{mg} / \mathrm{L})$} & \multirow{2}{*}{$\begin{array}{c}\text { Av. no. of multiple } \\
\text { shoots/ explant } \\
\text { (mean } \pm \text { S.E.)* }\end{array}$} & \multirow{2}{*}{$\begin{array}{c}\text { Av. length } \\
\text { of shoots }(\mathrm{cm} \\
\text { (mean } \pm \text { S.E.) }\end{array}$} \\
\hline BAP & Ads & IAA & NAA & & \\
\hline 0 & 0 & 0 & 0 & 0 & 0 \\
\hline 1.0 & 50 & 0 & 0 & $0.24 \pm 0.8 \mathrm{~h}$ & $0.88 \pm 0.4 \mathrm{f}$ \\
\hline 1.5 & 50 & 0 & 0 & $1.88 \pm 0.7 \mathrm{~g}$ & $1.12 \pm 0.6 \mathrm{e}$ \\
\hline 2.0 & 50 & 0 & 0 & $2.14 \pm 0.6 \mathrm{f}$ & $1.37 \pm 0.7 \mathrm{~d}$ \\
\hline 1.5 & 50 & 0.05 & 0 & $2.65 \pm 0.6 \mathrm{e}$ & $1.24 \pm 0.8 \mathrm{~d}$ \\
\hline 1.5 & 50 & 0 & 0.05 & $1.62 \pm 0.6 \mathrm{~g}$ & $0.94 \pm 0.8 \mathrm{e}$ \\
\hline 1.5 & 50 & 0.1 & 0 & $2.72 \pm 0.7 \mathrm{e}$ & $1.16 \pm 0.7 \mathrm{e}$ \\
\hline 1.5 & 50 & 0 & 0.1 & $1.32 \pm 0.5 \mathrm{~h}$ & $0.84 \pm 0.6 \mathrm{f}$ \\
\hline 1.5 & 100 & 0 & 0 & $5.25 \pm 0.6 \mathrm{c}$ & $2.03 \pm 0.6 \mathrm{~b}$ \\
\hline 2.0 & 100 & 0 & 0 & $5.54 \pm 0.8 \mathrm{c}$ & $2.20 \pm 0.8 b$ \\
\hline 1.5 & 100 & 0.05 & 0 & $8.20 \pm 0.9 \mathrm{a}$ & $3.22 \pm 0.7 \mathrm{a}$ \\
\hline 1.5 & 100 & 0.10 & 0 & $6.15 \pm 0.8 b$ & $3.14 \pm 0.6 \mathrm{a}$ \\
\hline 1.5 & 100 & 0 & 0.05 & $3.32 \pm 0.6 \mathrm{~d}$ & $1.65 \pm 0.8 \mathrm{c}$ \\
\hline 1.5 & 100 & 0 & 0.10 & $2.14 \pm 0.8 \mathrm{f}$ & $1.86 \pm 0.5 \mathrm{c}$ \\
\hline 2.0 & 100 & 0.05 & 0 & $6.02 \pm 0.8 \mathrm{~b}$ & $2.12 \pm 0.8 \mathrm{~b}$ \\
\hline 2.0 & 100 & 0 & 0.05 & $2.76 \pm 0.6 \mathrm{e}$ & $1.74 \pm 0.9 \mathrm{c}$ \\
\hline 1.5 & 100 & 0.25 & 0 & $2.83 \pm 0.5 \mathrm{e}+$ & $1.12 \pm 0.6 \mathrm{e}$ \\
\hline 1.5 & 100 & 0 & 0.25 & $1.76 \pm 0.7 \mathrm{~g}+$ & $0.83 \pm 0.5 \mathrm{f}$ \\
\hline 2.0 & 100 & 0.25 & 0 & $1.02 \pm 0.6 \mathrm{~h}+$ & $1.06 \pm 0.7 \mathrm{e}$ \\
\hline 2.0 & 100 & 0 & 0.25 & $1.08 \pm 0.7 \mathrm{~h}+$ & $0.74 \pm 0.6 \mathrm{f}$ \\
\hline
\end{tabular}

* 20 replicates/treatment; repeated thrice. Shoots with less than $0.25 \mathrm{~cm}$ length were not taken into account. Means having same letters are not significantly different by Duncan's multiple range test at the level of $5 \%$. + Callusing at the basal end.

Table III. Analysis of variance for the effects of BAP, Ads, NAA and IAA on production of multiple shoots (A) and average number of shoots per explant (B) from nodal explants of Acacia mangium after 4 weeks of culture.

\begin{tabular}{lccr}
\hline $\begin{array}{l}\text { Source } \\
\text { of variation }\end{array}$ & df & \multicolumn{2}{c}{ Mean squares } \\
\hline & & A & B \\
Replication & 19 & 4.56 & 0.635 \\
Treatments & 19 & $8668.27^{*}$ & $1207.82^{*}$ \\
Error & 361 & 2.02 & 0.234 \\
\hline
\end{tabular}

* Significant at $P<0.05$ as determined by the F-test.

among the twenty combinations tried (BAP, Ads, IAA and NAA), the combination of BAP $(1.5 \mathrm{mg} / \mathrm{L})$, Ads $(100 \mathrm{mg} / \mathrm{L})$ and IAA $(0.05 \mathrm{mg} / \mathrm{L})$ proved to be the most effective treatment for promoting shoot multiplication (6-8 shoots per nodal explant, each shoot having 3-4 nodes) within 4 weeks of subculture (Tab. II) (Fig. 1b). Analysis of variance for the effects of cytokinins and auxins on production of multiple shoots and average number of shoots/explant was presented in Table III. The interaction of two cytokinins with low concentration of auxin enhancing shoot multiplication has been reported by many authors $[3,5,12]$. The inclusion of higher concentration of auxin (either IAA or NAA) into the cytokinin rich medium inhibited not only shoot multiplication but also produced some compact callus at the base of the explants. Similar observations were made in Pterocarpus santalinus [8] and in Acacia auriculiformis [9].

\subsection{Rooting}

Elongated shoots derived from nodal explants (grown on MS medium supplemented with $1.0 \mathrm{mg} / \mathrm{L} \mathrm{BAP,} 1.0 \mathrm{mg} / \mathrm{L} \mathrm{GA}_{3}$ and $0.05 \mathrm{mg} / \mathrm{L}$ IAA) were separated and cultured on halfstrength basal MS medium supplemented with IAA, IBA and NAA alone or in combination for induction of rooting. Of the three auxins tested, IBA and IAA induced rooting (Tab. IV). The optimum concentration was $0.5 \mathrm{mg} / \mathrm{L}$ of IBA or IAA and it resulted in 65 to $70 \%$ of root initiation within 14-18 days of culture (Fig. 1c). At higher concentrations (1.0-1.5 mg/L) of IBA or IAA, the percentage of rooting was reduced and callus formation obtained at the basal cut end. Inhibition of rooting was observed on medium containing different concentrations of NAA. The combination of either IAA + NAA or IAA + IBA or IBA + NAA did not show any positive response on rooting, rather it formed callus at the cut end of the excised shoot and also the shoot became yellowish. These observations have also been reported for other woody species [14, 16, 17]. Monteuuis and Bon [18] reported that rooting of the mature clone was significantly increased by exposing the microshoots to $4-6 \mu \mathrm{M}$ IAA or IBA in darkness. In vitro grown rooted plants were removed from the adhering gel, transplanted to earthen pots and kept under high humidity for acclimatization. About $52 \%$ of the plantlets survived under greenhouse condition after one month of transfer. 
Table IV. Effect of IAA, NAA and IBA on in vitro rooting of Acacia mangium.

\begin{tabular}{|c|c|c|c|c|}
\hline \multicolumn{3}{|c|}{$\begin{array}{l}1 / 2 \mathrm{MS}+2 \% \text { sucrose }(\mathrm{w} / \mathrm{v})+ \\
\text { auxin concentration }(\mathrm{mg} / \mathrm{L})\end{array}$} & \multirow[t]{2}{*}{$\begin{array}{l}\text { Microshoot } \\
\text { rooted (days) }\end{array}$} & \multirow[t]{2}{*}{$\begin{array}{c}\% \text { of rooting } \\
(\text { mean } \pm \text { S.E. })^{*}\end{array}$} \\
\hline IAA & NAA & IBA & & \\
\hline 0 & 0 & 0 & 0 & 0 \\
\hline 0.25 & 0 & 0 & $17-18$ & $46.26 \pm 3.2$ \\
\hline 0.50 & 0 & 0 & 14 & $70.78 \pm 2.6$ \\
\hline 1.0 & 0 & 0 & $17+$ & $28.36 \pm 1.8$ \\
\hline 1.5 & 0 & 0 & $19+$ & $11.32 \pm 2.2$ \\
\hline 0 & 0.25 & 0 & + & + \\
\hline 0 & 0.5 & 0 & + & + \\
\hline 0 & 1.0 & 0 & + & + \\
\hline 0 & 1.5 & 0 & + & + \\
\hline 0 & 0 & 0.25 & $16-17$ & $54.24 \pm 2.4$ \\
\hline 0 & 0 & 0.50 & 13 & $65.23 \pm 3.8$ \\
\hline 0 & 0 & 1.0 & $16+$ & $32.62 \pm 1.3$ \\
\hline 0 & 0 & 1.5 & $18+$ & $24.18 \pm 1.6$ \\
\hline 0.5 & 0 & 0.25 & + & + \\
\hline 0.5 & 0 & 0.5 & + & + \\
\hline 0 & 0.25 & 0.25 & + & + \\
\hline 0 & 0.5 & 0.5 & + & + \\
\hline 0.25 & 0.25 & 0 & + & + \\
\hline 0.5 & 0.25 & 0 & + & + \\
\hline
\end{tabular}

* 10 replicates/treatment; repeated thrice. + Callusing at the basal cut end.

Table V. Description of the micropropagation steps of Acacia mangium.

\begin{tabular}{|c|c|c|}
\hline Step & Time (weeks) & Medium \\
\hline (1) In vitro bud proliferation & 2 & $\begin{array}{c}1.0 \mathrm{mg} / \mathrm{L} \mathrm{BAP}, 1.0 \mathrm{mg} / \mathrm{L} \mathrm{GA}_{3} \text { and } 0.05 \mathrm{mg} / \mathrm{L} \mathrm{IAA} \\
+3 \%(\mathrm{w} / \mathrm{v}) \text { sucrose }\end{array}$ \\
\hline (2) Shoot multiplication & 4 & $\begin{array}{c}5 \mathrm{mg} / \mathrm{L} \mathrm{BAP}, 100 \mathrm{mg} / \mathrm{L} \text { Ads and } 0.05 \mathrm{mg} / \mathrm{L} \\
+3 \%(\mathrm{w} / \mathrm{v}) \text { sucrose }\end{array}$ \\
\hline (3) In vitro rooting & 2 & $1 / 2 \mathrm{MS}, 0.5 \mathrm{mg} / \mathrm{L}$ IBA $+2 \%(\mathrm{w} / \mathrm{v})$ sucrose \\
\hline (4) Plantlet establishment & 4 & Garden soil:sand $(1: 1)$, Greenhouse $\left(30^{\circ} \mathrm{C}\right)$ \\
\hline
\end{tabular}

\subsection{Genetic stability}

Out of the twenty different primers tested, three primers (OPC-04, OPD-14 and OPC-19) produced good amplification products that were monomorphic across all the micropropagated plants. The size of the monomorphic fragments, produced by primer OPC-04 ranged from 2.58 to $23.2 \mathrm{~kb}$ (Fig. 1d). Other primers showed amplification with less number of monomorphic bands. There were no polymorphic DNA fragments among the micropropagated plants as well as the mother plant. The pattern of monomorphic bands in the in vitro raised plants were reported earlier in other plants using different primers [1, 7]. Rout et al. [13] reported that there was no variation in plants derived from meristem culture.

\section{CONCLUSION}

This study illustrates a successful micropropagation system for Acacia mangium, a leguminous tree. The micropropagation protocol is presented in Table V. The RAPD analysis indicates that the plant raised directly from the axillary meristems were genetically similar to the mother plant. Such a method will be helpful for propagation of superior trees for reforestation programmes.

Acknowledgements: The authors wish to acknowledge to the Department of Forests and Environment, Government of Orissa for providing necessary facilities for this study.

\section{REFERENCES}

[1] Angel F., Barney V.E., Tohme J., Roca W.M., Stability of cassava plants at the DNA level after retrieval from 10 years of in vitro storage, Euphytica 90 (1996) 307-313.

[2] Bousquet J., Simon L., Lalonde M., DNA amplification from vegetative and sexual tissues of trees using polymerase chain reactions, Can. J. For. Res. 20 (1990) 254-257. 
[3] Dhar U., Upreti J., In vitro regeneration of a mature leguminous liana (Bauhinia vahlii Wight and Arnott.), Plant Cell Rep. 18 (1999) 664 669.

[4] Harter H.L., Critical values for Duncan's Multiple range test, Biometric 16 (1960) 671-685.

[5] Jaiwal P.K., Gulati A., In vitro high frequency plant regeneration of a tree legume Tamarindus indica (L.). Plant Cell Rep. 10 (1991) 569-573.

[6] Kamis A., Taylor D. (Eds.), Acacia mangium: growing and utilization, MPTS monograph series, No. 3, Winrock International and FAO, Bangkok, Thailand, pp. 1-19.

[7] Kumar M.B., Barker R.E., Reed B.M., Morphological and molecular analysis of genetic stability in micropropagated Fragaria $\times$ Ananassa cv. Pocahontas, In Vitro Cell. Dev. Biol. Plant 35 (1999) 254 258.

[8] Lakshmi Sita G., Sreenatha K.S., Sujata S., Plantlet production from shoot tip cultures of red sandalwood (Pterocarpus santalinus L.), Curr. Sci. 62 (1992) 532-535.

[9] Mittal A., Agarwal R., Gupta S.C., In vitro development of plantlets from axillary buds of Acacia auriculiformis - a leguminous tree, Plant Cell Tissue Organ Cult. 19 (1989) 65-70.

[10] Murashige T., Skoog F., A revised media for rapid growth and bioassays with tobacco tissue cultures, Physiol. Plant. 15 (1962) 473 497.
[11] Raghava Swamy B.V., Himabindu K., Lakshmi Sita G., In vitro micropropagation of elite rosewood (Dalbergia latifolia Roxb.), Plant Cell Rep. 11 (1992) 126-131.

[12] Rout G.R., Das P., Micropropagation of Madhuca longifolia (Koenig) Mac Bride var. latifolia Roxb, Plant Cell Rep. 12 (1993) 513-516.

[13] Rout G.R., Reddy G.M., Das P., Studies on in vitro clonal propagation of Paulownia tomentosa STEUD. and evaluation of genetic fidelity through RAPD marker, Silvae Genet. 50 (2001) 208-212.

[14] Skolmen R.G., Acacia (Acacia koa Gray.), in: Bajaj Y.P.S. (Ed.), Biotechnology in Agriculture and Forestry, Trees-1, Springer-Verlag, Berlin, 1986, pp. 375-384.

[15] Tomar U.K., Gupta S.C., In vitro plant regeneration of leguminous trees (Albizia spp.). Plant Cell Rep. 7 (1988) 385-388.

[16] Upreti J., Dhar U., Micropropagation of Bauhinia vahlii Wight \& Arnott. - a leguminous liana, Plant Cell Rep. 16 (1996) 250-254.

[17] Yadav U., Lal M., Vijai S., Jaiswal V.S., Micropropagation of Morus nigra $\mathrm{L}$. from shoot tip and nodal explants of mature trees, Sci. Hortic. 44 (1990) 61-67.

[18] Monteuuis O., Bon M.C., Influence of auxins and darkness on in vitro rooting of micropropagated shoots from mature and juvenile Acacia mangium, Plant Cell Tissue Organ Cult. 63 (2000) 173-177. 